\title{
DO POLICIAL AO NOIR: \\ AS NOVAS FACES DA NARRATIVA VIOLENTA $\star$ \\ http://dx.doi.org/10.1590/1984-0292/1323
}

Paulo Sesar Pimentel $\star \star$ Instituto Federal de Educação, Ciência e Tecnologia de Mato Grosso - Campus Cuiabá - Bela Vista, MT, Brasil

\section{RESUMo}

O presente artigo se propõe a, num primeiro momento, descrever a evolução do gênero policial, do seu surgimento até sua transformação, numa nova categoria, designada por noir. Partindo deste ponto, trabalham-se as especificidades do chamado romance negro, suas motivações e suas peculiaridades, inseridas na estrutura social contemporânea, discutindo, por sua relação intrínseca, a violência e a morte. A fim de exemplificar esta construção narrativa, usa-se o conto "Tempestade sobre a Montanha", de Wander Antunes, numa análise que permite vislumbrar as manifestações temáticas e estruturais deste novo gênero adaptadas à realidade brasileira.

Palavras-chave: narrativa policial; noir; conto contemporâneo brasileiro; violência.

\section{From the POLICE NARRATIVE TO THE NOIR: THE NEW FACES OF NARRATIVE OF VIOLENCE}

\begin{abstract}
This article intends to, at first, describe the evolution of the detective genre, from its inception until its transformation into a new category, called noir. From this point, work the specificities of 'black romance, their motivations and their peculiarities, set in contemporary social structure, arguing for its intrinsic relationship, violence and death. In order to illustrate this narrative construction, it uses the story "Tempestade sobre a montanha", of Wander Antunes, an analysis paves the thematic and structural manifestations of the new genus adapted to the Brazilian reality.

Keywords: police narrative; noir; brazilian contemporary tale; violence.

\footnotetext{
^Artigo baseado na dissertação de Mestrado "O faroeste brasileiro: literatura, imaginário, violência e morte em Mato Grosso". Mestrado em Estudos da Linguagem (MeEL/ UFMT). Orientador: Dr. Mário Cezar Silva Leite. Cuiabá: UFMT, 2008. Grosso - Campus Cuiabá - Bela Vista. Av. Juliano Costa Marques, s/n - CEP: 78050-560. Cuiabá / MT.E-mail: paulo.pimentel.pimentel@gmail.com
}

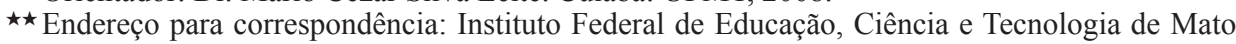


Crimes, criminosos, investigação, jagunços, mandantes e querelas, disputas e contratos, mortos e matadores, estes são motivos comuns na literatura de massa. Isso se dá graças ao gênero policial, amplamente desenvolvido e consumido por gerações diversas desde Edgar Allan Poe. Atribui-se geralmente a esse poeta e contista norte-americano a criação do moderno romance policial, também tratado por romance de intriga, ou romance de investigação (D'ONOFRIO, 1999, p. 166). Depois dele, a fórmula criada foi amplamente utilizada por diversos outros que, ao longo dos anos, desenvolveram intrigas dentro da estrutura proposta pelo criador ou, numa dialética inevitável, trafegaram por outros rumos, criando categorias novas, subdivisões e enfoques inusitados, revolucionando a literatura que foca diretamente o entretenimento. Falemos mais detalhadamente sobre isso.

Uma das coisas que nos incita e incomoda, até, ao pensarmos no romance policial, é como uma estrutura tão amplamente reproduzida e repetida pode, ainda hoje, duzentos anos depois, fazer sucesso junto ao público? De certo modo, a resposta nos é dada por Todorov ao afirmar que, quando se faz romance policial, nunca se inova, mas sempre se reproduz. Quanto mais fiel for o escritor quanto à norma estabelecida e canonizada, mais perfeita será a narrativa.

$\mathrm{O}$ romance policial tem suas normas; fazer melhor do que elas pedem é ao mesmo tempo fazer pior: quem quer embelezar o romance policial faz literatura, não romance policial (TODOROV, 2004, p. 95).

É interessante como o teórico, ao descrever um gênero da literatura, contradiz uma das regras de ouro da produção literária: no romance policial não se inova, uma vez que ele, por pertencer ao gênero de massa, nunca deve assustar ou surpreender o leitor pela estrutura. Cabem aos elementos da investigação presentes no enredo esse papel. Isso, segundo o próprio Todorov, é uma contraposição à grande arte.

Poder-se-ia dizer que todo grande livro estabelece a existência de dois gêneros, a realidade de duas normas: a do gênero que ele transgride, que dominava a literatura precedente e a do gênero que ele cria. Existe, entretanto, uma domínio feliz onde essa contradição dialética entre obra e seu gênero não existe: o da literatura de massa (TODOROV, 2004, p. 95).

Mas, já que partimos dos elementos de composição da narrativa policial, que, de acordo com a tradição, não poderiam ser alterados, é interessante comentá-los.

Por muito tempo, posterior a Poe, produziram-se romances policiais sem, propriamente, uma definição exata (e escrita) de sua estrutura. De certo modo, ao atender às expectativas de um público crescente e, a cada edição mais voraz e exigente, o autor trilhava os passos de seu motivador, chegando assim às estruturas empiricamente. O leitor, acostumado a determinadas normas e regras, aceitava, exaltava e, dicotomicamente, rejeitava as obras de acordo com seu enquadramento. Boileau-Narcejac (1991) citam as regras, primeiras, elencadas por Van Dine e seguidas meio que à risca por escritores de romance policial. De acordo com ele, 
não se deve colocar numa trama policial um caso de amor. Isso somente perturbaria o desenrolar da trama. Outro elemento indispensável à trama é a existência de ao menos um cadáver. Nas palavras de Boileau-Narcejac, "quanto mais morto estiver esse cadáver, melhor" (BOILEAU-NARCEJAC, 1991, p. 38). Postos esses elementos, é importante que o detetive aja com elementos estritamente realistas, sem apelos sobrenaturais ou construções inverossímeis. Isso porque, havendo um detetive, e apenas um (digno de assim ser chamado) no enredo, a teia narrativa deve se desvendar de forma lógica, seguindo uma certa linearidade, num primeiro momento até que imperceptível, mas depois, na apuração dos fatos e acontecimentos, clara e óbvia ao leitor.

Outro ponto importante é o equilíbrio entre assassino e detetive. Um detetive responsabiliza-se por um caso. Mais de um detetive seria injusto e desequilibrado. O culpado, alguém que tenha ao longo da narrativa desempenhado um papel importante, deve dispor de todos os meios para fugir e, se não o conseguir ao final da narrativa, o que ocorre com frequência na produção deste gênero, não o fará devido aos méritos do detetive. Inclusive, para manter esse equilíbrio, é interessante dotar o detetive de argúcia, mas também é preciso cuidar na escolha do culpado, não escolhendo serviçais ou personagens muito secundárias. Nas palavras de Van Dine "o culpado deve ser alguém que valha a pena” (BOILEAU- NARCEJAC, 1991, p. 39).

Outro elemento importante é a existência de apenas um culpado. Toda indignação do leitor deve sempre ser dirigida a apenas uma personagem, preferencialmente, se ela for dotada de maldade inquestionável e de uma moralidade completamente avessa aos valores morais e éticos da sociedade na qual esta inserida. Para tanto, o bom escritor policial deve ser aquele que dá indícios ao longo da composição da culpa de alguém, mas não entrega totalmente o criminoso, já que o leitor, se descobrir antes da última página o assassino, pode fechar o livro e descartá-lo. É necessário, então, encontrar o meio termo de entrega e recusa dos elementos, sendo esse um dos grandes motes da narrativa policial.

Essas citadas (e resumidas) características regeram a composição do romance policial direta ou indiretamente e, talvez fossem elas ainda a única regra de composição dessa tipologia textual, não fosse a irremediável evolução do gênero. De certo modo, o romance policial está ligado às revoluções que demandaram no êxito rural. Quanto maior a cidade, maiores os crimes e, paralelo a isso, a existência de criminosos de toda laia. A existência incógnita permite aos desejos mais profundos, escondidos e violentos, se manifestarem. Além disso, as condições sociais enfatizam desigualdades e criam as anomalias sociais. Forma-se assim "a cidade industrial, com seu cortejo de míseros, de desenraizados, prontos a tornarem-se capangas" (BOILEAU-NARCEJAC, 1991, p. 14).

Outro ponto importante é que nas grandes cidades, formadas a partir do século XVIII, com a primeira Revolução Industrial, e intensificadas na Segunda Revolução, no século XIX, tem-se uma acentuada formação, ou aparecimento, de 
tipos urbanos, coabitando e interagindo. Mesmo que não exista propriamente a ação violenta, pode haver a fabulação desta, baseada no acontecimento ou na ficção, que se propaga em novas histórias, em muitas versões, a partir de um enredo inicial.

[a cidade] é o espaço onde muitos crimes acontecem, estimulando a criação de histórias de temática policial, mas, sobretudo, porque é o espaço onde as narrativas se proliferam, onde circulam inúmeras versões sobre um mesmo acontecimento, que acabam por tornar inócua qualquer tentativa de conhecimento da realidade (FIGUEIREDO, 2003, p. 28).

A cidade é o espaço de recriação do crime, é o lugar em que o criminoso se renova, refaz e reinventa seus métodos. A narrativa que visa descrever esse universo emergente encontra terreno fértil, cada vez mais, diga-se, nas cidades, também cada vez maiores. Ali, o criminoso desaparece no anonimato. Torna-se, por definição, inatingível (BOILEAU-NARCEJAC, 1991, p. 15). Só que, se o crime se reinventa, é claro que o romance policial também precisa se reinventar. Chegamos então a um impasse. O que fazer de um gênero que se sustenta em uma estrutura dura, inflexível? Não nos esquecemos que, como disse Todorov (2004, p. 95), a melhor narrativa policial é justamente aquela que nada acrescentar a estrutura, mas, pelo contrário, adequar-se inteiramente a ela. Nas palavras de teórico "fazer melhor que elas pedem [as regras que regem o romance policial] é ao mesmo tempo fazer pior" (TODOROV, 2004, p. 94). Assim, para quebrar essa regra que até então se apresentava pétrea, é inevitável buscar dentro do próprio romance policial as fraquezas ou aberturas para a mudança. A dinâmica da própria literatura, das relações entre autor e leitor, são forças que atuam, inclusive, no questionamento de regras e obrigatoriedades. Assim, "é pelo jogo de espelhamento entre as posições do autor, do personagem e do leitor que a fantasia volta para desregular a boa relação da ordem do discurso" (FIGUEIREDO, 2003, p. 81). Esta mudança ocorreu no romance policial, dentro da pequena margem de flexibilidade que ele apresenta, gradativamente, passando pelo enfoque do detetive, do leitor contra o detetive, da vida como problema, para se apresentar como uma nova tipologia, o romance noir. É interessante explicar esta transição e este nascimento. Para Todorov, o mistério que a tudo engloba e de onde nascem todas as ações narrativas se tornará puro pretexto e o romance negro, que o sucedeu, dele se desembaraçou, "para elaborar, de preferência, essa nova forma de interesse que é o suspense e se concentrar na descrição do meio" (TODOROV, 2004, p. 104). Neste ponto, resgata-se a ideia, já posta anteriormente, de que a narrativa policial nasce com as grandes cidades, mas envolvida numa aura que gira em torno do mistério, da construção que exige habilidades intelectuais do escritor, ao formular a estrutura, das personagens, ao tentar desvendar o crime, ou, no caso do antagonista, escondê-lo, e do leitor, permitindo-se mergulhar na trama e atuar em conformidade com o protagonista. A estabilização das grandes cidades, entretanto, fortalece o meio, o espaço, o topos, por si só interessantes como trama, como enredo. Segundo Salvatore D’Onofrio (1999, p. 167), 
Como ensinam os formalistas russos, a literatura evolui da própria literatura. Um gênero literário, individualizado pelo agrupamento de obras que possuem formas estéticas e conteúdos ideológicos semelhantes, como qualquer elemento vivo, tem seu surgimento, seu apogeu, sua fase de estandardização, em que se formam estereótipos que levam ao seu declínio e à sua transformação em um novo gênero. O processo de transformação ocorre pela presença, dentro das obras de um mesmo gênero, de topoi, lugares-comuns, parcelas de significação fixas e constitutivas do gênero, ao lado de outros elementos estéticos e significativos que variam de uma obra para outra. A primeira espécie de topoi são chamados por Tomacheviski de motivos associados, a segunda de motivos livres. Quando um motivo livre, por sua presença constante num grupo de obras, passa a ser associado, isto é, obrigatório, constitutivo, temos a separação dessas obras do gênero original e a formação de um novo gênero.

Como já dito, o romance policial precisa ter uma estrutura rígida que, partindo de um exercício de raciocínio, consiga se desvendar de forma lógica, revelando o assassino e, mais que isso, apontando as justificativas para o (s) ato (s), sendo as grandes cidades o cenário perfeito para isso ocorrer. Temos, então, nas palavras de Todorov duas histórias: "a história do crime e a história do inquérito" (TODOROV, 2004, p. 96). Na primeira, tem-se, partindo da existência de um cadáver, poucos elementos que são entregues pelo narrador para que se comece a investigação. Esta constitui a segunda e mais importante parte da narrativa: o inquérito. Nele, outros elementos devem ser desvendados, descobertos, combinados e/ou desprezados, para que, ao final, com um mosaico de informações se chegue, não só ao culpado, como também às razões do crime. São duas histórias que, combinadas, resultam na grande narrativa e esse seria o topoi constitutivo. A partir de quando estrutura-se a narrativa focando a segunda história, em detrimento da primeira e, às vezes, inclusive, abandonando a primeira, com elementos como a violência, o meio, a corrupção tanto por parte do culpado, como é usual, mas também por parte do detetive e de quem detém a lei e o poder de efetuar justiça, temos motivos livres que, irremediavelmente, minam a estrutura antiga, propondo a nova. Isto quer dizer que, na narrativa policial clássica, a "história do crime" é tão importante quanto a história do inquérito, uma vez que ambas dialogam neste eixo de lógica que envolve o desvendar do crime pelo detetive e, irremediavelmente, pelo leitor. Já na nova, a violência não exige uma razão, o crime desonera-se da função de ter motivos. Sendo assim, o inquérito, ou seja, todas as forças empreendidas para desvendar um crime, é o que se destaca, sem a necessidade, como acontece com a narrativa policial, de se ter uma verossimilhança que justifique qualquer ato.

Analisemos então o próprio termo que visa a diferenciar esse novo gênero, ou ainda, por subsistir dentro da narrativa policial, esse subgênero. A palavra noir, de origem francesa, pode ser traduzida como negro. $\mathrm{O}$ termo serve ao caráter de- 
fendido pela estrutura narrativa, uma vez que não mais se pensa em se condenar ou prender o antagonista. Mais do que isso, o jogo não mais se centra na tentativa de se descobrirem as técnicas, o contexto ou os culpados por um assassinato. Não há mais a necessidade de uma lógica que, mesmo implícita, mova a trama. Claro é que isso não quer dizer que não haja elaboração. Pelo contrário, a elaboração se dá por outros meios, ou ainda, numa outra perspectiva. Descreve-se o enredo pelo prisma do possível assassino, pelos olhos astutos, doentios ou justiceiros do próprio antagonista. Acrescenta-se ainda a elaboração psicológica que permite ao leitor se identificar não mais com a lei, mas com outro sistema que passe a reger uma certa ordem social, sem passar, por exemplo, pela constituição federal que deveria ordenar e reger aquele espaço, aquele grupo.

Pensando no romance policial, analisando sua evolução hoje, com os olhos postos sobre sua história e estruturação, fica-nos a inevitável sensação de que surgiria a criação do Noir, conforme afirma Boileau-Narcejac (1991, p. 57):

Não era fatal que o assassino fosse um réplica do detetive, uma espécie do detetive do avesso. Bem pelo contrário, podia-se também facilmente fazer do detetive uma réplica do assassino, uma espécie de criminoso pelo avesso.

No jogo de espelhamentos citado pelos teóricos, a narrativa evolui com um assassino que apreende técnicas e assume comportamentos que antes, no romance policial, eram apenas utilizados na construção do protagonista, do detetive. Dotado de charme e argúcia, os assassinos descritos no romance noir poderão despertar a empatia que, antes, eram prerrogativas do representante do bem e da ordem, tecendo novas relações de identificação do leitor com os atos, com as causas. Do mesmo modo, para agir e desvendar crimes, ou tentar fazê-lo, uma vez que, no noir, nem sempre o final é fechado, o criminoso exposto e a ordem reestabelecida, o detetive passa a atuar com técnicas e ações muitas vezes dúbias e questionáveis, moralmente e até eticamente. Estabilizado o topos, as grandes cidades, desestabiliza-se, numa confusão de tipos, as personagens, que, em muitos momentos, acabam por se confundir.

Desse modo, no primeiro caso, no romance policial, o que teríamos seria a lógica se apoderando de todas as partes da narrativa, e, no segundo, a violência dominando. Para Todorov (2004, p. 99) há, no segundo caso apresentado, a existência pulsante do romance noir, uma vez que, citando Marcel Duhamel (apud BOILEAU-NARCEJAC, 1991, p. 64), há "a violência - sob todas as formas" e acrescentaríamos que, dentro dessa abertura do rígido policial, em todos os lugares. O que podemos perceber então é que o romance negro não mais necessita do detetive, ou ainda de normas de composição estruturais rígidas e inflexíveis que engessam o detetive num padrão de comportamento. Não há mais necessidade de um processo de apresentação, mas sim de um meio apresentado, de personagens e lugares que comovam ou impressionem o leitor por motivos além de razão imediata e perceptível. O presente não mais pode ser exclusivamente recolhido, sem restos, das encarnações sucessivas da razão. Isso quer dizer que no romance negro, os temas, postos num meio hostil, são o eixo e a plumagem que enfeita a narrativa, 
não necessariamente bebendo da fonte conhecida, mas criando, a partir de dados, uma estrutura social que assusta, afasta e dialeticamente, atrai, aproxima e encanta por uma palavra, a violência. Esta, obviamente, dialoga com nossa subjetividade, com o universo que criamos ao nos inserirmos nos grandes espaços urbanos, onde a surpresa, o desconhecido, o impensado se manifesta com frequência e engana ou subverte qualquer lógica ou estrutura pré-determinada. Para Todorov "é em torno dessas constantes que se constitui o romance negro: a violência, o crime geralmente sórdido, a amoralidade das personagens" (TODOROV, 2004, p. 100). Todas as outras histórias paralelas que existirem no noir tem função secundária, subordinada e não mais central, como acontecia no romance policial de enigma.

Boileau-Narcejac aponta a América como terreno propício para o surgimento do noir. Temos um faroeste, marcado por "xerifes que defendem a lei de maneira desembaraçada [...] tem-se ainda, na tradição do Oeste, os policiais-rufiães treinados para atirar primeiro" (BOILEAU-NARCEJAC, 1991, p. 58), caçadores de prêmio que, para prender a caça, usam todos os artifícios, legais e ilegais, morais, imorais ou amorais. Com o crescimento das cidades norte-americanas, prosperaram todos os tipos de vícios sociais, tais como a prostituição, os jogos, as drogas, as extorsões. Mais ainda, há a política que, num espaço corrupto, também assim se torna. Sendo assim, é possível manipular os eleitores pela ameaça, pelo terror e pelo dinheiro. Por esse expediente, o poder pertence ao mais forte. Assim temos o poder centrado nas mãos do submundo, a lei controlada por grupos corrompidos. A polícia, nesse caso, é comprada e surge o particular, ou seja, os mandantes e os mandatários, figuras ambíguas que vivem num limiar invisível a separar ou fundir a ordem e o caos, num discurso de promoção da vida pela morte, da paz pela violência, esta, necessária, mesmo que contraditória àquela. Assim, "a violência é um elemento constitutivo do romance policial" (BOILEAU-NARCEJAC, 1991, p. 19) e o noir se utiliza dessa violência, presente no romance policial, muito intensificada, para se constituir, tendo nas cidades modernas o lócus perfeito para o inevitável, o inesperado e o novo, ordenado ou subversivo, caótico e contraventor ou esperado e, ainda assim, aterrorizador e sangrento.

Marcel Duhamel (apud BOILEAU- NARCEJAC, 1991, p. 64) define assim o espírito do romance negro, ao abrir a Série Noir, na França:

Que o leitor não prevenido desconfie: os volumes da Série Noire não podem, sem perigo, ser postos em todas as mãos. $\mathrm{O}$ amador de enigmas à Sh. Holmes frequentemente não achará proveito neles. O otimismo sistemático também não. A imoralidade, em geral admitida nesse gênero de obras, unicamente para servir de contraste a moralidade convencional, aí está naturalmente tanto quanto belos sentimentos como a moralidade simplesmente. O espírito é raramente conformista. Aí se veeem policiais mais corrompidos que os malfeitores que perseguem. O detetive simpático nem sempre resolve o mistério. Às vezes, não há mistério. E algumas vezes, nem detetive. Mas então? [...] Então, restam ação, angústia, violência - em todas as suas 
formas e, particularmente, as mais imfamantes - , sova e massacre [...] Há também amor - preferivelmente bestial, paixão desordenada, ódio sem piedade; todos sentimentos que, numa sociedade civilizada, só se considera que tem curso muito excepcionalmente. Mas que são aqui moeda corrente. E são às vezes expressos numa língua muito pouco acadêmica, mas em que sempre domina, rosa ou negro, o humor.

Um ponto importante do romance negro diz respeito à vida das personagens. Há no clássico romance policial ou de investigação uma espécie de contrato informal, mas extremamente válido, de que ao detetive nada ocorra. Mas do que isso, há a necessidade de se preservar os suspeitos antes da descoberta do crime e a explanação dos atos que o levaram a tal. Mesmo que um dos suspeitos se fira, sempre ficarão muitos outros, sendo que deve existir um leque de possibilidades para se atribuir a culpa. Isso quer dizer que "essas personagens gozavam de imunidade" (TODOROV, 2004, p. 100) e o mal sempre deverá ser vencido plenamente. Há, inclusive, no processo de identificação do leitor com a personagem, no caso, o herói, a necessidade desta imunidade, o que cria a sensação da ordem se sobrepondo, mesmo que a duras penas, ao caos, fazendo com que o próprio leitor seja uma extensão desta ordenação do mundo. De acordo com Salvatore D’Onofrio (1999, p. 178):

O herói da literatura de massa, pouco importa se agindo dentro, à margem ou fora do sistema policial, representa o símbolo do desejo de salvaguardar os valores sociais, lutando contra os elementos perturbadores da ordem, inimigos do estado e dos cidadãos integrados na sociedade. Por isso, o detetive, como o mocinho do filme de faroeste, não pode ser derrotado: sua vitória é um imperativo ideológico. De antemão, o consumidor de literatura de massa sabe que o mocinho, apesar de apanhar na primeira parte do filme, no final vencerá o vilão [...] a justiça triunfará sobre a iniquidade, o amor sobre o egoísmo, a liberdade sobre a opressão, enfim, o bem sobre o mal. A maldade é colocada na literatura de massa apenas para ser aniquilada.

Desse modo, reitera-se a estrutura, sem muitos espaços para construções subjetivas, e veicula-se um componente ideológico de forte sustentabilidade em relação aos gostos do público consumidor. Essa regra, aparentemente informal entre o escritor e o leitor, implicitamente rígida, se considerarmos a produção de massa, precisa ser quebrada, atendendo aos novos gostos, emergentes com as flutuações e flexibilizações pelas quais passa a estrutura social, com um senso de justiça que pode, de indivíduo para indivíduo, especialmente, num grande contingente de pessoas, se esgarçar e dar espaço, entre as fendas, para o surgimento de novos artefatos e artifícios. Em outras palavras, Hannerz (1997, p. 17) afirma que "às vezes, o limite é visível, outras vezes não. É melhor entendê-lo como um ziguezague ou uma linha pontilhada", portanto mutável e extremamente fugidio. 
Isto quer dizer que, quando passamos à narrativa noir, esse contrato de imunidade se desfaz. As personagens, quaisquer sejam elas, detetives, suspeitos (culpados ou não) e todas as demais envolvidas, viram vítimas em potencial e, a cada golpe ou lance de sorte/azar, "elas arriscam constantemente a vida" (TODOROV, 2004, p. 101), podendo, inclusive, perdê-la. Desse modo, no romance negro, o traço principal é que as personagens perdendo a imunidade, sendo espancadas, feridas, arriscando constantemente a vida, em resumo, estando integradas no universo dos mortais, ao invés de serem observadores independentes, criam uma espécie de verossimilhança maior e, por conseguinte, criam mais emoção e aproximação com o mundo que conhecemos.

Nesse contexto, somos obrigados a reiterar a questão da violência. Como já alertou Marcel Duhamel em seu prefácio, já apresentado, à Série Noire, na narrativa noir não há moralidade. Pelo menos não moralidade gratuita, ou seja, aquela que não necessita de justificativas para existir, ou que é aceita sem contestações pela maior parte do público, pois está impregnada na estrutura daquela tipologia narrativa e já é esperada pelo leitor. Se ela aparecer e, geralmente, isto ocorre, servirá apenas para se contrastar a uma imoralidade mórbida, grotesca, beirando o absurdo ou aquele comportamento que a sociedade não quer nomear. São os crimes mais hediondos, premeditados, dolosos, carregados de um ódio cego, disparado contra pessoas sem culpa, ou, distorcendo a máxima da justiça, pessoas que sempre são de algum modo culpadas de algo, até que se prove o contrário. Mais que isto, ao usarmos o termo disparado, há um valor conotativo, mas também denotativo, pois pode remeter à bala, tornando o crime no romance negro mais agressivo e sanguinolento. Além da bala, nele são aceitos pedras, paus, as próprias mãos, com unhas cortantes e que servem para verter a maior quantidade de sangue possível, abortos grosseiros, mal feitos, cruéis, caçadas injustas, facas e facões, punhais, canivetes, enfim, tudo o que de certo modo pode ser usado de forma assustadora em favor da violência, via de regra, gratuita (BOILEAU-NARCEJAC, 1991, p. 37).

É interessante notar como a questão da violência, tão inerente ao ser humano, resvala em conceitos que retomam os valores da estética naturalista. Há um clima de torpeza, de vilania que precisa ser instaurado, posto em pessoas que antes seriam pacatos fazendeiros, pobres e desanimados desempregados, urbanos ou rurais, policiais enlouquecidos ou ainda entregues totalmente à tirania e à corrupção. Nesse tipo de narrativa, temos uma sociedade de corrompidos, marcados com firmeza para desempenhar as funções mais algozes da história humana. Se todos estes elementos, sempre estiverem presentes, acrescidos de muito sangue (reitera-se aqui isso propositadamente), temos a típica narrativa noir.

Ora, se pensarmos que a violência insidiosa e infame se dá na sociedade moderna, nada nos impede de buscar suas bases na formação dessa sociedade. Isso quer dizer que, diretamente falando, as estruturas violentas hoje conhecidas, e descritas pela literatura, têm seu berço na formação dos estados modernos. Os Estados Unidos da América, por exemplo, passaram por turbulências de toda ordem, políticas, econômicas, conflitos de classes, gerando-se ao longo de sua história, às vezes, confundida com a própria história, a partir de crimes, um longo e abrangente rol de violências.

Fractal, Rev. Psicol., v. 26 - n. esp., p. 679-694, 2014 
Partindo destas explanações, há, aplicando estas inovações a uma narrativa exemplar, a construção de uma ruptura do policial e esta nova composição narrativa. Para tanto, faz-se uso de um conto "Tempestade Sobre a Montanha" (ANTUNES, 2002, p. 29), do brasileiro, residente no estado de Mato Grosso, Wander Antunes.

\section{O NOIR EM W ANDER ANTUNES}

O século XX foi um período de profundas transformações na literatura e nas artes de modo geral. Com o aprimoramento de técnicas, com a própria tecnológica, as rápidas e as sucessivas mudanças e readequações pelas quais o ocidente passou, as artes foram constantemente bombardeadas por novidades, ou ainda, num movimento dialético e complementar, bombardeando o mundo com a primazia de propostas ou de interpretações do mundo. Esse período de grandes mudanças, entretanto, passou. ${ }^{1} \mathrm{O}$ que hoje se apresenta, comumente, é a renovação ou reutilização de formas pré-existentes, relidas e ressignificadas, conforme afirma Canclini (2003, p. 49):

Dado que o máximo valor estético é a renovação incessante, para pertencer ao mundo da arte não se pode repetir o já feito, o legítimo o compartilhado. Devem-se iniciar formas de representação não codificadas, inventar estruturas imprevisíveis, e relacionar imagens que, na realidade, pertencem a cadeias semânticas diversas e que ninguém tinha associado.

O que temos hoje, no que se convenciona chamar período contemporâneo, são ressignificações: formas e estruturas já consagradas foram retomadas e hibridizadas, gerando novas cadeias semânticas. Esses elementos são transferidos para um plano que as remolda, reestrutura e reinventa. Temos, em matéria de arte, a reordenação constante do já feito e do já utilizado. Desse modo, não se é fiel a um gênero, mas a vários. Sendo assim, misturá-los e colocá-los em fluxo, dessacralizando obras, autores e histórias, é uma das grandes novidades da contemporaneidade (CANCLINI, 2003, p. 32).

A arte tende, então, cada vez mais, a afastar-se dos procedimentos de ruptura, das negações radicais, que supunham afirmações também radicais. Em vez da revolução, a transgressão. Isto é, não se trata de fundar um novo lugar, mas de trabalhar com a violação permanente de fronteiras - misturando tempos, espaços e remodelando continuamente identidades (FIGUEIREDO, 2003, p.12).

Segundo Figueiredo, então, não existe mais a necessidade de radicalmente romper, mas de sutilmente violar, ou agressivamente transgredir. Mais do que isso, a arte passa a mesclar elementos diversos, compondo, a partir do já conhecido e usado, o novo, o inédito, por mais antitético que isso seja. As velhas formas se combinam e criam uma estrutura, ou ainda, uma proposta nova. Isto é o que temos em "Tempestade sobre a montanha", de Wander Antunes (2002). 
O noir, como já explanado, é a libertação da estrutura rígida que formava o romance policial. Faz a melhor narração policial aquele que seguir à risca as normas e regras do gênero. Qualquer acréscimo, qualquer criatividade seria um atentado à ordem estabelecida e consagrada. Já o noir é justamente a quebra desses paradigmas. A proposta é valer-se de todos os elementos do policial, mas numa combinação original, tirando do leitor certezas, justificativas e conclusões. Resumindo de certo modo, não há no noir esperanças, nem razões. O que há são atos, violentos e, geralmente, muito cruéis.

O conto "Tempestade sobre a montanha" narra, em terceira pessoa, a história de dois velhos, Ernesto e Argemiro, agricultores, que, movidos pela esperança de ganhar um prêmio do governo, decidem matar Emílio Rufo, inimigo do estado. Os dois velhos, sem terras, pobres e marginais em relação ao sistema latifundiário mato-grossense, se valem de uma única espingarda com a qual acertam o foragido Emilio Rufo. Temerosos de não o terem matado, os dois discutem sua situação, a traição do governo ao prometer e não cumprir, a perda da terra e a recompensa que esperam ganhar. Por fim, eles descem a montanha em direção ao alvo, ferido ou morto, eles não sabem, e Argemiro derruba seus óculos que se partem em vários pedaços. Ernesto, com o rifle, agora emperrado na mão, decide usá-lo para cacetear a cabeça do foragido, mas antes disso ocorrer, tropeça e cai, batendo a cabeça em uma das muitas pedras afiadas da montanha. Morto Ernesto, o quase cego Argemiro procura sua faca e ao não a encontrar, apanha uma pedra, com a qual martela a cabeça de Emilio Rufo até sentir a pasta viscosa em que se transformara a cabeça do revolucionário. "Não se importa mais com o governo ladrão, com cegueira, com tempestade. Com mais nada. Nem com o uivo cada vez mais próximo e ameaçador dos lobos" (ANTUNES, 2002, p. 29).

Por contraposição, o surgimento das grandes cidades reitera e ratifica peculiaridades atribuídas às pequenas, à sombra, mostrando no micro a violência que se manifesta no macroespaço. É interessante, de imediato, notar que o embate político dos grandes centros desloca-se para espaços ermos, neste caso, o estado de Mato Grosso. O conflito político, o inimigo do estado, desloca-se para todos os espaços e, com ele, vai a possibilidade de uma justiça que escapa e que deve ser conquistada à força, seja na multidão das urbes, seja nos ermos do cerrado.

As duas personagens do conto em questão, ao se prepararem para assassinar um inimigo do governo, discutem sua posição na estrutura social. É interessante notar que, no conflito de terras, que teve como resultado a segmentação dos protagonistas, temos o argumento usado para a prática da violência e seu resultado mais grotesco, ou seja, a morte. Segundo Peregrina Cavalcante, ao criar uma tipologia de assassinos, há um tipo que muito se aproxima dessas duas figuras: o caça-recompensas. Ele está sempre ligado a um mandante, direto ou indireto, no presente caso, o governo. Ele não possui ou não quer possuir a autonomia para praticar crimes por vontade própria. Ele, inclusive, possui espaços certos para atuação e, sempre, a vontade do mandante predomina na ação do matador (CAVALCANTE, 2003, p. 155). 
Um outro elemento importante na composição do conto, como recurso no desenho literário sobre o imaginário mato-grossense, é o narrador. De certo modo, ao se utilizar a narração em $3^{a}$ pessoa, cria-se uma impressão eufemística, de narração policial, com acontecimentos ordenados numa seqüência temporal que explora, passo a passo, o máximo de intensidade crítica dessas duas personagens marginais. Mais do que isso, com a narração em $3^{a}$ pessoa, aproxima-se o leitor de um universo que, aparentemente, numa sociedade capitalista e moderna, não mais existe. A crueldade da miséria, a opressão da margem social, as personagens obrigadas às piores crueldades são retratadas gradualmente, causando, no decorrer dos acontecimentos de "Tempestade sobre a montanha", uma espécie de empatia entre quem lê, no plano extratexto, e quem vive, no intratexto. Isso é resumido por Figueiredo (2003, p. 43) da seguinte forma:

Um narrador em terceira pessoa que pudesse servir como instância mediadora entre o leitor burguês e o personagem marginalizado pela sociedade, correndo o risco de imprimir um tom paternalista e, portanto, mitificador, à narrativa.

Voltando à questão da violência, valem mais algumas reflexões sobre o tópico. Um dos principais problemas do fenômeno da violência é sua origem e sua pluricausalidade. Poderíamos apontar razões ligadas às necessidades biológicas, ou ligadas à motivação individual, ou ainda, como um fenômeno de causalidade social provocada, ora por ruptura da ordem, ora pela vingança dos oprimidos, ora pela fraqueza do Estado, mas, ainda assim, seria praticamente impossível determinar todas as suas causas.

A violência não é um fenômeno social recente. No entanto, as suas manifestações, pela velocidade das comunicações, se revelam, na atualidade, com mais intensidade, assim como os agentes nelas envolvidos. O novo, no que toca à violência, parece ser a pluralidade de formas que ela assume na atualidade, sendo algumas especialmente graves, sendo que sua crescente incidência chega a configurar o que, em vários momentos, no senso comum, de uma cultura da violência.

Para nós, no momento, o que vale, ao pensarmos no conto e em violência, é tecer uma relação entre a vingança dos oprimidos e a ineficiência do estado em tratar de determinadas questões, nesse caso, a agrária nos sertões do país. No conto de Wander Antunes, a discussão dos dois assassinos do foragido do governo, durante um período de espera, se dá em torno da recompensa. Temos, aí, dois pontos que devem ser considerados.

O primeiro, expresso, é a questão da terra e o protecionismo do estado governamental em detrimento do cidadão. "- Culpa do governo! Culpa do governo! Garantiu que ia comprar a safra. Não cumpriu sua palavra e deixou o banco tomar tudo da gente" (ANTUNES, 2002, p. 26). Nesse ponto, falidos e sem a preciosa terra, as personagens num certo desespero pela sobrevivência, passam a agir em busca de outras fontes. Topamos, nesse ponto, com a violência como forma de sobrevivência. Claro que isso é uma desculpa num primeiro momento. Logo, o que se tem, é uma espécie, por parte das personagens, ou melhor, de uma das perso- 
nagens, de um processo catártico de descarrego de raiva e emoções contrastante, no rosto do foragido, que ao final do conto se torna uma massa de sangue diante da pedra do agressor. A violência do assassinato começa, então, com um discurso de necessidade de sobrevivência, mas perde sua sustentação e se torna, na figura da vítima, a punição que não é feita pela justiça, mas, pelo contrário, fere a essa em sua mais elementar base, o direito à vida.

Se há uma justificativa para determinada ação, como apontamos no primeiro ponto, por outro lado, nesse que é o segundo, o que temos é a antiga relação humana de caça-recompensas. Independente de qualquer contexto social justificante ou não, assassinos em busca de recompensa são tipos antigos. Nesse caso, é interessante pensarmos também no espaço em questão. O assassino contratado, chamado aqui de jagunço, é uma "forma de existência, como realização ontológica no mundo do sertão" (CANDIDO, 1977, p. 149). Partindo dessa definição proposta por Candido, se há realização ontológica, o que temos é o tratamento do ser enquanto ser e, mais ainda, do ser concebido como tendo uma natureza comum que é inerente a todos e a cada um dos seres, marcada pela violência como forma de existência. Logo, independente da motivação, recompensa apenas, ou recompensa como forma de se atingir uma justiça inexistente, o que temos é a brutalidade do assassinato, crime hediondo em quase todas as culturas ocidentais. Essa violência, de acordo com a característica essencial apontada por Candido, ontológica, é parte integrante do indivíduo que, num meio e momento prescritos e determinados, pode se manifestar, independente de qualquer distinção social.

Isso faz com que, num espaço violento, o homem, independentemente de qualquer profissão, raça, cor ou credo, pode, ou é, em potencial, vítima e algoz da violência. Antonio Candido (1977, p. 148), ao analisar a jagunçagem, diz "por isso é que, sendo as condutas tão relativas e o mundo tão cheio de reversabilidade, não há barreiras marcando a separação. $\mathrm{O}$ homem pode ser hoje soldado e amanhã jagunço, ou o contrário". Nesse caso, o homem violento, em busca de um retorno, uma recompensa, pode ser de qualquer esfera social, mas, como a necessidade faz o algoz, ou a vítima, as camadas mais marginalizadas acabam por sofrer mais, em um ou outro lado da relação de violência e morte.

O pequeno latifundiário, então, mandatário, assume as ordens do seu mandante e age onde o sistema legal não consegue, não quer ou não pode agir. Isso está, claro, sempre inserido em um processo. Pensemos nesse processo na forma como ele se configura, gradualmente. $\mathrm{O}$ pequeno proprietário de terras não consegue manter sua propriedade e, consequentemente, a parte, sendo esta incorporada a grandes latifúndios.

O processo de marginalização se completa nesse ponto, que, paradoxalmente, é seu grande motivador. Ao se perderem as terras, perde-se também a condição de subsistência e, diante disso, aplica-se o processo de reversabilidade, citado anteriormente em Candido. Há, em Tempestade sobre a Montanha, um momento em que não se sabe mais se o que temos é somente um agricultor desesperado ou um agricultor que sempre fez as vezes de assassino alugado. "Ah, mas se não fosse por minha informação, você não teria nada, ia estar esperando o go- 
verno atender seu pedido de aposentadoria... há anos que espera e nada. Acha que eles vão pagar aposentadoria pra pistoleiro? Ri! Ri!" (ANTUNES, 2002, p. 26). De um modo ou outro, a violência crua se apresenta ao leitor, indicando no conto a presença de elementos da narrativa noir, tais como a ausência da imunidade, a violência crua, o sangue abundante, vertido por ações que escapam à legislação vigente, na lei feita pelo próprio punho, mesmo vivendo as personagens num tempo que se apresenta como civilizado, mas que dá continuidade à barbárie, com a diferença de que se permite que isto vire narrativa artística.

Numa leitura lexical, violência é a adjetivo do agressivo, do bruto e leva ao constrangimento, físico ou moral. Sendo mais abrangente, pode-se definir a violência como toda forma de sujeição antijurídica que coloca ou predispõe a vítima a qualquer forma de sofrimento.

Partindo disso, afirmamos que a jagunçagem implica um mundo muito mais abrangente e largo que o da própria violência, porque se separa do caráter imediato desta para se desdobrar em segmentações cada vez mais elaboradas e planejadas, de modo a garantir determinada ordem que, não necessariamente, seja a ordem estabelecida juridicamente. Sendo assim, qualquer ação nesse plano resultar em dano ao humano e transgressão da norma estabelecida. A violência assume, por direções oblíquas da jagunçagem, uma sutileza que a torna cada vez mais cruel e/ou hedionda.

Nesse contexto de violência, geralmente se tem os seguintes elementos: o socioeconômico, já que o trabalho se baseia em dicotomia entre a elite, capitalista, proprietária dos meios de produção, para usar um léxico já conhecido, e os marginais do sistema, subgrupo despossuído e transformado em constantes vítimas da crueldade social ligada, neste caso, à posse de terra. Os poderosos valem-se de todo tipo de poder social existente, sendo o principal o poder econômico, conquistado a partir de grandes extensões de terra, e/ou o poder político. Nas palavras de Figueiredo (2003, p. 22) "numa sociedade fortemente estratificada, é no mundo do crime que as diferentes classes sociais acabam por se encontrar", tendo por amálgama, neste caso, a violência, simbólica, física, ou ambas, justapostas e combinadas, do mandante, incógnito, e dos mandados, explicitando as frustrações que se convertem em ações.

Não há, no presente caso, uma profissionalização prévia do crime, mas uma série de ações que conduzem às personagens ao ato. Como afirma Candido (1977, p. 138) "De um motivo mínimo, na sua futilidade inesperada, pode surgir o criminoso e, daí, o profissional do crime". Tomando essa afirmação por base, as menores razões são sempre suficientes para se construir um cenário de violência e morte. Quando, nessa lógica, pensamos em pessoas que, de certo modo, perderam tudo, o que se constrói é, sem dúvidas, um cenário totalmente desolador. É o que se percebe na fala de uma das personagens de "Tempestade sobre a montanha": "Culpa do governo! Culpa do governo! Garantiu que ia comprar a safra. Não cumpriu sua palavra e deixou o banco tomar tudo da gente. Ah, você sabe... você também perdeu suas terras. Essa gente do governo não presta!!" (ANTUNES, 2002, p. 26). Nessa perspectiva, todas as ações tentam, por parte das perso- 
nagens, ser justificadas. Mata-se porque não se tem opção para sobreviver. "Mas agora vão ter que nos dar o dinheiro da recompensa. Não matamos o Emilio Rufo, o revolucionário?" (ANTUNES, 2002, p. 26). O que temos então são "seres suspensos no nada, mergulhados num estado de orfandade e que por isso vagam sem lei, sem identidade fixa, desafiando a lógica e a psicologia" (FIGUEIREDO, 2003, p. 20). Já que deles tudo foi retirado, o que, senão o instinto primitivo, pode devolver um mínimo de esperança pela sobrevivência?

Como única garantia de vida, essas figuras, que representam uma opressão explícita, na terra distante de tudo, marcada pela luta braçal pela sobrevivência pura e simples, buscam a recompensa sonhada, o dinheiro que não mais pode, nos confins do mundo civilizado, ser conquistado dentro da lei e da ordem estabelecida. Torna-se preocupação não mais matar, mesmo que isso seja brutal e antiético. A preocupação é receber o dinheiro: "os lobos comem e aí como é que nós vamos receber a recompensa?" (ANTUNES, 2002, p. 27). Por fim, nessa desesperada luta por sobrevivência, na tentativa de se reconquistar algo perdido, vem novamente o medo do governo e do poder, o mesmo que antes marginalizou essas figuras. "Pensa, homem, pensa. Nós vamos ser enganados de novo, o governo que vai sair ganhando... como sempre" (ANTUNES, 2002, p. 27). O contrassenso aqui é o fato de o estado, responsável (em teoria, ao menos) pela ordem social, ser o culpado por todas as desgraças que se abateram sobre as personagens. Mais do que isso, o estado, que é quem deveria defender o indivíduo, estabelecendo a igualdade, é quem pode e, se puder, vai enganar essas tristes figuras. Mas é justamente ao estado que elas servem na luta pela vida. O inimigo do estado, Emilio Rufo, será morto por vítimas do estado que, servindo a este, explicitam a afirmação de Candido (1977, p. 142) "a ordem privada se prepara para usar a violência contra a violência". Matar o inimigo do estado é a forma que estes sertanejos miseráveis encontram de tomar do estado, pela recompensa, o que lhes foi antes negado ou usurpado. Assim, há "o ritual de justiça sertaneja sob a forma de vingança privada” (CANDIDO, 1977, p. 142).

\section{CONSIDERAÇÕES FINAIS}

Na geografia dos espaços violentos, conforme já dissemos, as implicações sobre uma nova ordem social residem na ausência de antigas. Isto é uma espécie de particularização no tratamento desse tema, pois a violência é tema recorrente na literatura, clássica, romântica e contemporânea, e na dramaturgia (remontando as tragédias gregas).

De acordo com Oricchio, a particularização do tema violência e sua respectiva consequência é resultado de uma série de fatores nascentes no mundo moderno. A narrativa que surge das relações capitalistas, nos séculos XIX e XX, é caracterizada pelo "clima de desespero e fatalismo de seu universo dramático" (ORICCHIO, 2003, p. 186) e que se fundamenta sempre como fundo no período da Grande Depressão, onde o desemprego e as carências gerados pela crise da sociedade fazem aparecer personagens agressivas, em ininterrupta luta pela sobrevivência, circulando por narrativas de investigação, com protagonistas heróis 
que desvendam crimes por meio da dedução lógica. Nesse universo surge o noir, ou seja, aquele que derruba a crença vigente na eficiência da justiça e na punição dos culpados, ao revelar na ficção a violência e a morte impunes, crimes que não têm solução, ou ainda, enigmas que encobertam outros ainda piores. Infelizmente, esta é uma das faces da sociedade contemporânea que a arte não se eximiu de representar, criando para isto, tipologias e formas novas ou redefinidas, em todas as suas cores, sendo o vermelho e o negro os tons mais acentuados e vigentes.

\section{Nota}

${ }^{1}$ Sobre este ponto, é interessante também a abordagem feita por Renato Ortiz (2003).

\section{REFERÊNCIAS}

ANTUNES, W. Trabalhinho em Cáceres e Tempestade sobre a Montanha. In: MORENO, J.; LEITE, M. C. S. (Org.). Na margem esquerda do rio: contos de fim de século. São Paulo: Via Lettera, 2002. p. 25-29.

BOILEAU-NARCEJAC. O Romance Policial. São Paulo: Ática, 1991.

CANCLINI, N. G. Culturas híbridas. São Paulo: Edusp, 2003.

CANDIDO, A. Vários escritos. São Paulo: 2 Cidades, 1977.

CAVALCANTE, P. Como se fabrica um pistoleiro. São Paulo: Girafa, 2003.

D'ONOFRIO, S. Teoria do texto: prolegômenos e teoria narrativa. 2. ed. São Paulo: Ática, 1999. v. 1.

FIGUEIREDO, V. L. F. de. Os crimes do texto. Belo Horizonte: UFMG, 2003.

HANNERZ, U. Fluxos, fronteiras, híbridos: palavras-chave da antropologia transnacional. Mana, [S.1.], v. 3, n. 1, p. 7-39, abr. 1997.

ORICCHIO, L. Z. Cinema de novo: um balanço crítico da retomada. São Paulo: Estação Liberdade, 2003.

ORTIZ, R. Mundialização e cultura. São Paulo: Brasiliense, 2003.

TODOROV, T. As estruturas narrativas. Tradução de Leyla Perrone-Moisés. São Paulo: Perspectiva, 2004.

Recebido em: 02 de julho de 2014 Aceito em: 03 de setembro de 2014 